\title{
SPATIAL DISTRIBUTION OF PLECOPTERA NYMPHS IN STREAMS OF A MOUNTAINOUS AREA OF CENTRAL BRAZIL
}

\author{
BISPO, P. C., ${ }^{1}$ FROEHLICH, C. G. ${ }^{2}$ and OLIVEIRA, L. G. ${ }^{3}$ \\ ${ }^{1}$ Museu de Zoologia, USP, C.P. 42694, CEP 4299-970, São Paulo, SP, Brazil \\ ${ }^{2}$ Departamento de Biologia, FFCLRP, USP, Av. Bandeirantes, 3900, CEP 14040-901, Ribeirão Preto, SP, Brazil \\ ${ }^{3}$ Departamento de Biologia Geral, ICB, UFG, Campus Samambaia, C.P. 131, CEP 74001-970, Goiânia, GO, Brazil \\ Correspondence to: Pitágoras C. Bispo, Museu de Zoologia, USP, C.P. 42694, CEP 4299-970, \\ São Paulo, SP, Brazil, e-mail: egfroeh@usp.br \\ Received March 26, 2001 - Accepted May 17, 2001 - Distributed August 31, 2002
}

(With 2 figures)

\begin{abstract}
In this paper the spatial distribution of Plecoptera nymphs in the Almas' River basin, Pirenópolis, GO, was studied. Two Surber samples, each comprising 20 sampling units and totalling $2 \mathrm{~m}^{2}$, were taken in each of the 13 stations, one during the rainy season (January 1994) and the second during the dry season (July 1994). In 5 of these stations, monthly samplings were made from June 1993 to July 1994; in these, temperature, velocity, discharge, electrical conductivity and pH were measured. Regional rainfall was also obtained. To ascertain the distribution of nymphs in the habitat, a separate sample was taken. Of the factors considered, the most important affecting the spatial distribution of the stonefly nymphs were altitude, stream order, and anthropic influence. Locally, the genera Anacroneuria and Kempnyia showed clumped distributions, but the data for Gripopteryx and Tupiperla were inconclusive due to low numbers.
\end{abstract}

Key words: Plecoptera, nymphs, spatial distribution, Central Brazil.

\section{RESUMO}

\section{Distribuição espacial de ninfas de Plecoptera em córregos de uma região serrana do Brasil Central}

A distribuição espacial de ninfas de Plecoptera em córregos da microbacia do Rio das Almas, Pirenópolis, GO, foi estudada. Foram feitas duas amostragens (amostrador de Surber, 20 unidades de amostra aleatórias $-2 \mathrm{~m}^{2}$ ) em 13 pontos de coleta, uma na estação chuvosa (janeiro/1994) e outra na estação de seca (julho/1994). Em cinco desses pontos, as coletas foram feitas mensalmente de junho/ 1993 a julho/1994. Nesses pontos foram registrados também a temperatura, a velocidade, a vazão, a condutividade elétrica e o pH, além da pluviosidade para a região. Para verificar se os plecópteros possuem distribuição agregada ou não, foi realizada coleta no ponto com maior riqueza de Plecoptera, onde as subamostragens foram individualizadas e posteriormente submetidas a análises estatísticas. Os fatores mais importantes na distribuição espacial dos plecópteros foram a altitude, a classificação hidrológica e a ação antrópica. Quanto à agregação, os gêneros Anacroneuria e Kempnyia tiveram distribuição agregada. Gripopteryx e Tupiperla tiveram distribuição aleatória, porém, em razão do baixo número, o resultado deve ser considerado inconclusivo.

Palavras-chave: Plecoptera, ninfas, distribuição espacial, Brasil Central. 


\section{INTRODUCTION}

The spatial distribution of Plecoptera nymphs can be influenced by several factors as chemical factors, altitude, temperature, stream size, vegetable cover, microhabitats and substratum type (Macan, 1962; Hynes, 1976; González del Tánago, 1984; Puig, 1984; Wais, 1984; Hassage \& Stewart, 1991). The nymphs are found in riffles and litter accumulations in microhabitats with high water movement (Hynes, 1976; Williams \& Feltmate, 1992; Froehlich \& Oliveira, 1997). There are species that live in the margins of cold oligotrophic lakes in places where water movements occur (Hynes, 1976; Harper \& Stewart, 1996). These insects are frequently associated with cold and clean streams (Williams $\&$ Feltmate, 1992). In the tropical area, many taxons are limited to mountainous and/or forested areas. The Plecoptera nymphs are conspicuous elements in fast, clean and cold waters with stone bottoms (Macan, 1962; Bachmann, 1995; Harper \& Stewart, 1996).

In previous papers (Bispo et al., submitted a and b), the Plecoptera fauna of Almas' River basin, Pirenópolis, GO, was studied in terms of the faunistic composition and the temporal variation of nymphs and adults. In this paper the spatial distribution of nymphs is considered as well as some factors that could explain this distribution are discussed.

\section{MATERIAL AND METHODS}

\section{Study area}

Fig. 1 shows Almas' River basin. The sources of this river are located in the Serra (Range) dos Pireneus, Pirenópolis, Goiás State, and comprise a number of streams descending steep slopes with stony or sandy bottoms but also with some pools retaining leaf accumulations. These streams run on the western slopes of the range and are part of the Amazon basin.

The area, according to Nimer (1989), presents a semi-humid tropical climate with a summer rainy season (higher pluviosities from December to February) and a winter dry season from May to September.

\section{Collections and taxonomic identification}

Thirteen sampling stations were chosen (Fig. $1)$; their characteristics are presented in Table 1. Each station was sampled twice, once during the rainy season (January 1994) and once during the dry season (July 1994). Five stations (1, 4, 6, 11 and 12) were sampled monthly from June 1993 to July 1994; an additional collection was made in May 1997 in station 1 (Inferno Stream), the station with the highest taxa richness, to ascertain whether the nymphs presented a clumped distribution.

The hydrological classification follows Strahler (1957). For the degree of canopy cover and degree of anthropic influence, scales from 0 to 3, based on a subjective evaluation, were set as follows: 0none, 1-small, 2-medium, 3-large (Table 1).

Nymphs were collected in riffles with a Surber sampler with an area of $0.1 \mathrm{~m}^{2}$ and a 0.225 mm mesh, following Lind (1979) and Merritt \& Cummins (1996). In each station, 20 random sampling units were taken, totalling $2 \mathrm{~m}^{2}$. The collected material was fixed in $5 \%$ formalin. In the laboratory, the material was sorted out and the stonefly nymphs were identified and preserved in $80 \%$ ethyl alcohol. For the additional collection of May 1997, ten sampling units were taken, each was sorted out individually and the results were submitted to a statistical analysis.

Plecoptera nymphs were determined to genus, the possible level to nymphs in the region, mainly using the keys of Benedetto (1974) and Froehlich (1984). The nymphs of each genus were deposited in the Zoological Museum, USP.

\section{Abiotic factors}

Air and water temperatures, water velocity, discharge, electrical conductivity and $\mathrm{pH}$ were measured in stations 1, 4, 6, 11 and 12. Water and air temperatures were measured with an alcohol thermometer $\left(0-50^{\circ} \mathrm{C}\right)$. Water velocity by the float method and discharge by multiplying velocity by the area of a cross-section of the stream (Lind, 1979). Electrical conductivity and $\mathrm{pH}$ were measured by a CORNING PS-17 and a CORNING PS-15 field meters, respectively. Regional monthly average temperatures and precipitation for Pirenópolis were obtained at the 10th Meteorological District, Ministry of Agriculture, Goiânia, GO. 


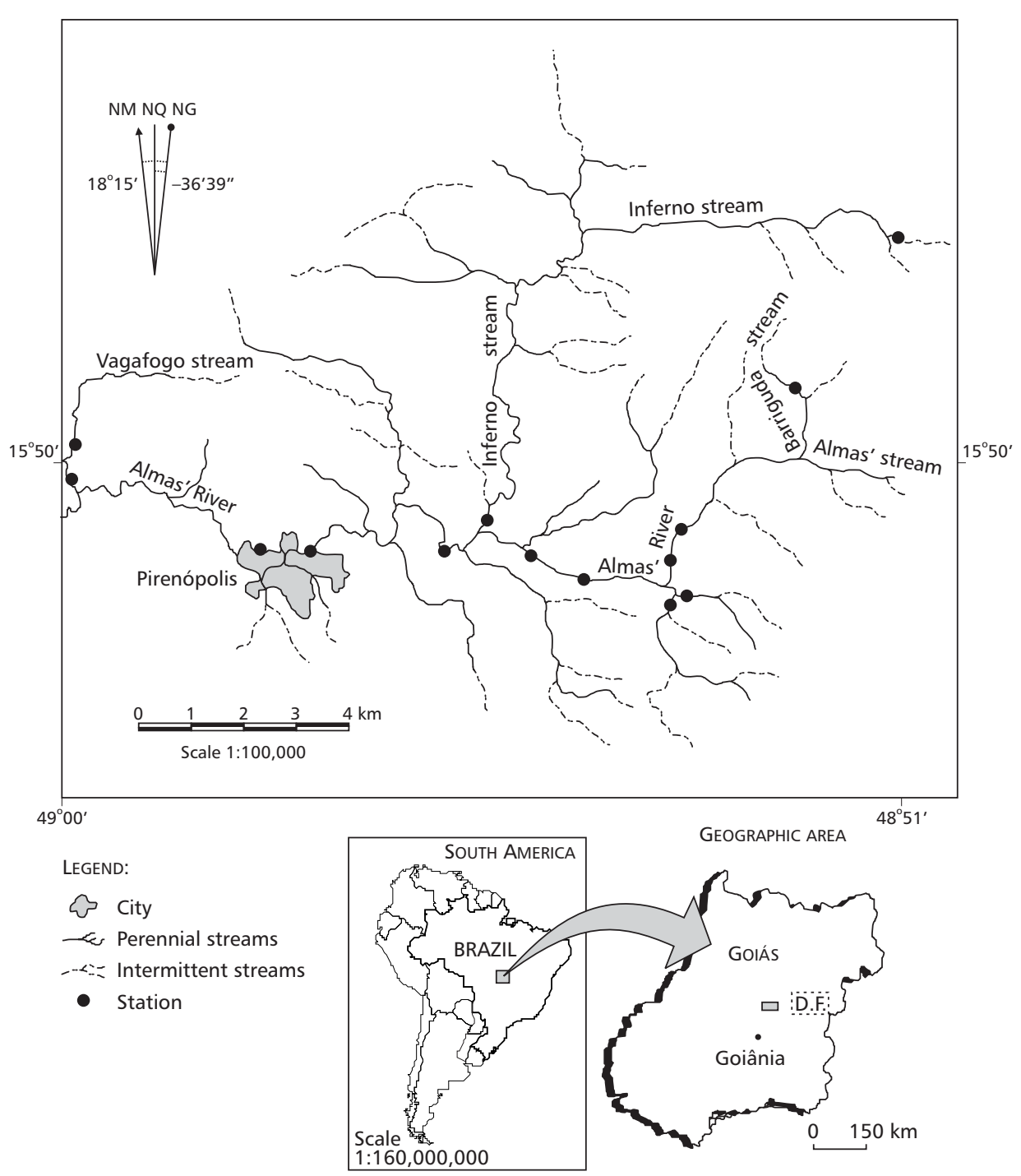

Fig. 1 - Map of the Almas' River basin, Pirenópolis Municipality, GO, showing the sampling stations.

\section{Statistics}

The paired t-test was used to verify differences between the Plecoptera fauna in the two seasons. According to Resh (1979), a clumped distribution is very common among aquatic insects. To test this, a separate sampling made up of 10 samplings units, was made in station 1, Inferno Stream, where the largest richness of stonefly nymphs was found. Dispersion (ID) was evaluated by the ratio between variance and the mean, and the statistical significance was evaluated by a $\chi^{2}$ test $\left[\chi^{2}=\operatorname{ID}(\mathrm{N}-1)\right]$ (Ludwig \& Reynolds, 1988).

\section{RESULTS AND DISCUSSION}

Various authors studied the spatial distribution of benthic insects (Illies, 1964; Lillehammer \& Brittain, 1987; Dominguez \& Valdez, 1992; Albariño, 1997) because it provides important information on the environmental conditions and on the organisms' responses to the patchiness of the lotic habitat. The size of the water body, the interaction with the riparian vegetation and the anthropic actions are important factors when studying the spatial distribution of aquatic organisms (Bispo \& Oliveira, 1998; Diniz-Filho et al., 1998). 
TABLE 1

Characterization of the 13 sampling stations in the Almas' River basin, Pirenópolis, GO.

\begin{tabular}{|c|c|c|c|c|c|}
\hline & Site & $\begin{array}{c}\text { Stream } \\
\text { classification }\end{array}$ & $\begin{array}{l}\text { Degree of } \\
\text { canopy cover }\end{array}$ & $\begin{array}{l}\text { Degree of } \\
\text { anthropic } \\
\text { influence }\end{array}$ & Altitude \\
\hline Station 1 & Inferno Stream & 1 st & 3 & 0 & $1100 \mathrm{~m}$ \\
\hline Station 2 & Barriguda Stream & 1 st & 2 & 1 & $950 \mathrm{~m}$ \\
\hline Station 3 & Almas’ River, up Fráter & $3 \mathrm{rd}$ & 2 & 1 & - \\
\hline Station 4 & Almas’ River, Fráter & $3 \mathrm{rd}$ & 2 & 1 & $780 \mathrm{~m}$ \\
\hline Station 5 & Tributary of Almas' River, OMNI & $3 \mathrm{rd}$ & 2 & 1 & - \\
\hline Station 6 & Almas’ River, club & 4th & 1 & 2 & $750 \mathrm{~m}$ \\
\hline Station 7 & Almas' River, down club & 4th & 1 & 2 & - \\
\hline Station 8 & Almas’ River, up quarry & 4th & 1 & 2 & - \\
\hline Station 9 & Almas' River, quarry camping & 4th & 1 & 2 & - \\
\hline Station 10 & Almas' River, city & 4th & 0 & 3 & - \\
\hline Station 11 & Almas' River, city & 4th & 0 & 3 & $730 \mathrm{~m}$ \\
\hline Station 12 & Vagafogo Stream & $1 \mathrm{st}$ & 3 & 0 & $710 \mathrm{~m}$ \\
\hline Station 13 & Vagafogo Stream & 1 st & 3 & 0 & - \\
\hline
\end{tabular}

0 - none; 1 - small; 2 - medium; 3 - large.

During the present study, 1501 nymphs were collected, 513 in the rainy season (pluviometric precipitation in January 1994: $325.3 \mathrm{~mm}$ ) and 988 in the dry one (pluviometric precipitation in July 1994: $17.4 \mathrm{~mm}$ ) (Tables 2 and 3). Table 2 shows the abundance in each station in the rainy and dry seasons. A significant difference was found between the densities of both seasons (Paired ttest, $\mathrm{p}<0.05)$. Station 1 had the largest overall abundance, 372 nymphs; station 10 had the smallest, with 3 nymphs (Table 2).

Diniz-Filho et al. (1998), studying the spatial distribution of the Ephemeroptera, Plecoptera and Trichoptera (EPT) fauna of the Pirenópolis region, and Bispo \& Oliveira (1998), studying the EPT fauna of the Goiânia Ecological Park, found differences among the communities in the rainy and the dry seasons. The temporal variation of Plecoptera nymphs from Pirenópolis region, studied by Bispo et al. (submitted a), showed a non- seasonal pattern. However, in the present paper there was a significant difference between the abundance of Plecoptera nymphs in the rainy (January 1994) and the dry (July 1994) seasons; these months are the extremes of the two seasons.

The hydrological classification of lotic waters is extremely important when considering the spatial distribution of macroinvertebrates. With growing stream order, interactions between abiotic and biotic factors vary, influencing the distribution of the groups (Vannote et al., 1980). Froehlich (1969) and Froehlich \& Oliveira (1997) observed the preference of some Plecoptera species for different stream sizes. Froehlich \& Oliveira (1997) suggest that in some cases the preference may be related to water velocity, as often stream size and water velocity are related (Hynes, 1970). In low order streams, the vegetable cover tends to be dense (Vannote et al., 1980), this occurred in the streams studied in the Perinópolis area. 
TABLE 2

Total number of nymphs collected during the rainy (January 1994) and the dry (July 1994) seasons in the Almas' River basin, Pirenópolis, GO.

\begin{tabular}{|c|c|c|c|c|c|c|c|c|c|c|c|c|c|c|}
\hline Stations & 1 & 2 & 3 & 4 & 5 & 6 & 7 & 8 & 9 & 10 & 11 & 12 & 13 & Total \\
\hline \multicolumn{15}{|l|}{ RAINY SEASON } \\
\hline Anacroneuria & 84 & 30 & 15 & 13 & 15 & 14 & 9 & 85 & 35 & 3 & 14 & 66 & 78 & 461 \\
\hline Kempnyia & & 15 & & & & & & & & & & & & 15 \\
\hline Gripopteryx & 23 & 4 & & & & & & & & & & & & 27 \\
\hline Tupiperla & 9 & 1 & & & & & & & & & & & & 10 \\
\hline Total & 116 & 50 & 15 & 13 & 15 & 14 & 9 & 85 & 35 & 3 & 14 & 66 & 78 & 513 \\
\hline \multicolumn{15}{|l|}{ DRY SEASON } \\
\hline Anacroneuria & 174 & 36 & 75 & 68 & 95 & 109 & 49 & 62 & 77 & & 2 & 61 & 60 & 868 \\
\hline Kempnyia & 28 & 28 & & & & & & & & & & & & 56 \\
\hline Gripopteryx & 2 & 9 & & & & & & & & & & & & 11 \\
\hline Tupiperla & 52 & 1 & & & & & & & & & & & & 53 \\
\hline Total & 256 & 74 & 75 & 68 & 95 & 109 & 49 & 62 & 77 & & 2 & 61 & 60 & 988 \\
\hline GRAND TOTAL & 372 & 124 & 90 & 81 & 110 & 123 & 58 & 147 & 112 & 3 & 16 & 127 & 138 & 1501 \\
\hline
\end{tabular}

In the Pirenópolis area, Kempnyia and Macrogynoplax preferred 1st order streams and highest vegetable cover (Tables 2 and 3), only one specimen of Kempnyia was collected in station 4, 3rd order (Table 3). Gripopteryx and Tupiperla preferred 1st order streams, highest vegetable cover and highest altitude (Table 2).

Anacroneuria is a very diversified group, it was represented in the Pireneus Mountains by 8 morphospecies (Bispo et al., submitted b) and occurred in all the collection stations (Table 2).

According to Bachmann (1995), the spatial distribution of the Plecoptera is closely linked to higher latitudes and altitudes. Hynes (1941 apud Macan, 1962) states that altitude influences these organisms through temperature (higher altitudes, lower temperatures); besides the direct effect of temperature on the aquatic organisms there is also the effect of an increased oxygen solubility. Temperature and oxygen solubility are negatively correlated and their combination can restrict the occurrence of some Plecoptera taxa to definite altitudes or latitudes, as is known from North America (Pennak, 1978). Corroborating Illies (1964), the present study showed that altitude was one of the main factors influencing the distribution of the stoneflies. In Brazil, the gripopterygids are characteristic of the mountainous areas of the south and southeast; in the studied area, they occurred only in stations 1 and 2 (Table 2), where altitudes are above $950 \mathrm{~m}$ a.s.l. (Table 1). In the other sampling stations, with lower altitudes (between 800 and $700 \mathrm{~m}$ a.s.1.), only Perlidae were found (Table 2), with the exception of a single Tupiperla nymph collected, in a separate sampling, in station 12 (710 $\mathrm{m}$ a.s.1.) (Table 3).

When studying the spatial distribution of aquatic macroinvertebrates, one important aspect is the anthropic influence and their responses to it (Schroeder-Araujo \& Cipólli, 1986; Hellawell, 
1989; Rosenberg \& Resh, 1993). Among the organisms sensitive to water quality, the Plecoptera occupy an outstanding position for their vulnerability to environmental impacts. Many methods for the evaluation of water quality consider the stoneflies as good indicators of clean waters (Navas-Pereira \& Henrique, 1996).

Donald (1980) and Simpson (1980) described morphological deformities in stoneflies exposed to inorganic pollution. Wielgosz et al. (1982) verified the absence of Plecoptera and other stenoic taxa in places with organic pollution. Considering the five stations collected along the year, a total of 3513 specimens were collected, $45 \%$ in station $1,19 \%$ in station $4,9 \%$ in station $6,1 \%$ in station 11 and $26 \%$ in station 12 (Fig. 2). The physicochemical characterization of these five stations are presented in Table 4. There was a large reduction in stonefly nymph abundance in stretches with a pronounced anthropic influence and larger stream order (Table 1 and Fig. 2). The increase of the size of the stream was coincident with the increase of the anthropic influence, being difficult to separate which of the two influenced more the decrease of the Plecoptera density. However, probably the influence of anthropic action (organic pollution) was a very important factor in the variation of the Plecoptera density among the stations (McCafferty, 1981; Wielgosz et al., 1982; Rosenberg \& Resh, 1993; Giller \& Malmqvist, 1998). The organic enrichment due to the discharge of organic sewage in the system can decrease the dissolved oxygen concentration and the Plecoptera gills can become covered with fine particles, hindering gaseous exchanges. Both can be related to the decrease in abundance of nymphs observed where the anthropic actions are higher.

Lotic habitats are composed of many microhabitats. This environmental mosaic affects the spatial distribution of the organisms (Scarsbrook \& Townsend, 1993; Allan, 1995). This heterogeneity favours the aggregation of organisms in microhabitats that offer them optimal conditions (resource availability, water velocity, substrate, etc.) for their development and survival. Besides the abiotic factors, interactions with other organisms may also affect their distribution (Hart, 1992). Hassage et al. (1988) verified a clumped distribution for the stonefly Pteronarcella badia. When submitted experimentally to the presence of a predator stonefly, Claassenia sabulosa, the distribution became random.

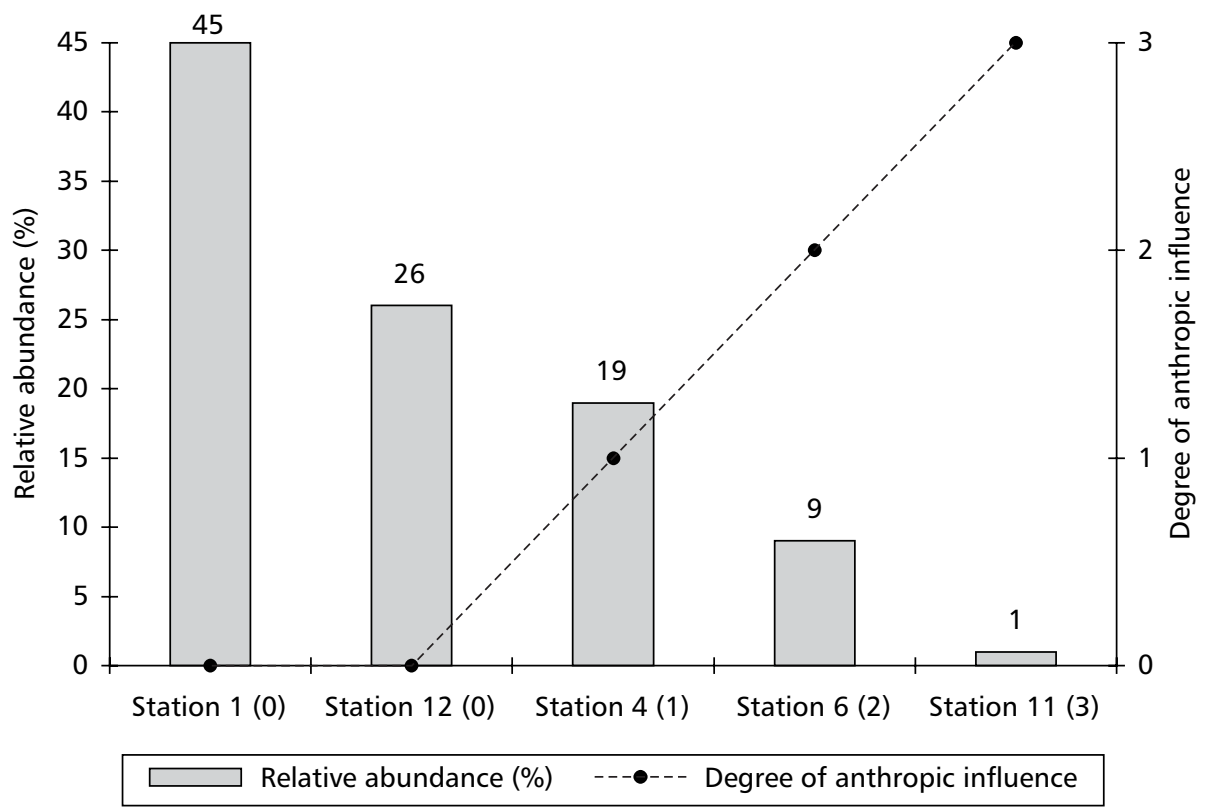

Fig. 2 - Graph of the relative abundances of nymphs collected from June 1993 to July 1994 in stations 1 , 4, 6, 11 and 12, and the respective degrees of anthropic influence, parenthesis, in Almas' River basin, Pirenópolis, GO. 
TABLE 3

Genera of Plecoptera nymphs recorded from June 1993 to July 1994 in stations 1, 4, 6, 11 and 12 in Almas' River basin, Pirenópolis, GO. 1: only one specimen.

\begin{tabular}{|l|c|c|c|c|c|}
\hline Stations & $\mathbf{1}$ & $\mathbf{4}$ & $\mathbf{6}$ & $\mathbf{1 1}$ & $\mathbf{1 2}$ \\
\hline Anacroneuria & $\mathrm{X}$ & $\mathrm{X}$ & $\mathrm{X}$ & $\mathrm{X}$ & $\mathrm{X}$ \\
\hline Kempnyia & $\mathrm{X}$ & 1 & & & $\mathrm{X}$ \\
\hline Macrogynoplax & $\mathrm{X}$ & & & & $\mathrm{X}$ \\
\hline Gripopteryx & $\mathrm{X}$ & & & & \\
\hline Tupiperla & $\mathrm{X}$ & & & & 1 \\
\hline
\end{tabular}

Ferreira (1990) and Oliveira (1991) found clumped distributions for most Ephemeroptera and Trichoptera in the area of Pedregulho, SP. Regarding the temporal variation, these authors verified that in some months the pattern became random, probably due to a reduction in numbers of these insects.

Most insects in the Almas' River basin showed a clumped distribution, corroborating Resh (1979), who considers this pattern a common one in the aquatic insects. Statistical analyses showed a clumped distribution for Anacroneuria and Kempnyia. Gripopteryx and Tupiperla were randomly distributed, a common result when numbers are very low. The clumped distribution is a problem in the evaluation of the density and sampling procedures in the study of aquatic insects. In communities with highly clumped distributions, a great number of samples are necessary for reducing the sampling error. Often ecological patterns are not detected on account of the large sampling error. Compared methodological studies are necessary in tropical areas in order to establish the best cost-benefit between the sampling effort and the associated error. Resh (1979) and Merritt et al. (1996) discuss some of those problems in aquatic insects.

In a general manner it can be said that altitude, anthropic influence and stream order were the chief factors conditioning the spatial distribution of Plecoptera nymphs in Almas' River basin.

TABLE 4

Mean and standard deviation of the abiotic factors recorded from June 1993 to July 1994 in sampling stations 1, 4, 6, 11 and 12, and the average precipitation for the area of the Almas' River basin, Pirenópolis, GO.

\begin{tabular}{|c|c|c|c|c|c|}
\hline Stations & 1 & 4 & 6 & 11 & 12 \\
\hline Water temperature $\left({ }^{\circ} \mathrm{C}\right)$ & $18.61 \pm 1.21$ & $19.07 \pm 1.78$ & $20.49 \pm 2.10$ & $20.42 \pm 2.60$ & $20.64 \pm 1.99$ \\
\hline Air temperature $\left({ }^{\circ} \mathrm{C}\right)$ & $20.61 \pm 1.92$ & $21.25 \pm 3.76$ & $22.61 \pm 3.21$ & $22.00 \pm 4.38$ & $22.07 \pm 2.63$ \\
\hline Water velocity $(\mathrm{m} / \mathrm{s})$ & $0.29 \pm 0.08$ & $0.48 \pm 0.14$ & $0.66 \pm 0.25$ & $0.83 \pm 0.25$ & $0.38 \pm 0.13$ \\
\hline Discharge $\left(\mathrm{m}^{3} / \mathrm{s}\right)$ & $0.04 \pm 0.02$ & $0.65 \pm 0.38$ & $0.79 \pm 0.58$ & $3.09 \pm 2.39$ & $0.26 \pm 0.18$ \\
\hline $\mathrm{pH}$ & $7.41 \pm 0.27$ & $8.31 \pm 0.18$ & $8.42 \pm 0.23$ & $8.24 \pm 0.21$ & $7.54 \pm 0.21$ \\
\hline Electrical conductivity $(\mu \mathrm{S} / \mathrm{cm})$ & $0-19$ & $10-29$ & $20-39$ & $10-29$ & $10-29$ \\
\hline & January/1994 & July/1994 & & & \\
\hline Precipitation for the area $(\mathrm{mm})$ : & 325.3 & 17.4 & & & \\
\hline
\end{tabular}


Acknowledgments - We would like to express our thanks to FUNAPE-UFG, for financial support during field work; to CAPES and to FAPESP (proc. 98/11074-3), for previous and present scholarships to the first author; and to $\mathrm{CNPq}$ for a research fellowship to the second (301247/96-0) and third (300833/98-9) authors.

\section{REFERENCES}

ALBARIÑO, R. J., 1997, Spatial distribution of Plecoptera from an Andean-Patagonic lotic environment in Argentina. Revta. Brasil. Biol., 57(4): 629-636.

ALLAN, J. D., 1995, Stream Ecology. Structure and Function of Running Waters. Chapman \& Hall, London, XII+388.

BACHMANN, A. O., 1995, Insecta Plecoptera. In: E. C Lopretto \& G. Tell (eds.), Ecosistemas de aguas continentales. Metodologías para su estudio. Ediciones Sur, La Plata, 3o vol., pp. 1093-1111.

BENEDETTO, L., 1974, Clave para la determinación de los plecopteros sudamericanos. Stud. Neotrop. Fauna Environ., 9: 141-170.

BISPO, P. C. \& OLIVEIRA, L. G., 1998, Distribuição espacial de insetos aquáticos (Ephemeroptera, Plecoptera e Trichoptera), em córregos de cerrado do Parque Ecológico de Goiânia, Estado de Goiás. In: J. L. Nessimian \& A. C. Carvalho (eds.), Ecologia de insetos aquáticos. Oecol. Bras., UFRJ, Rio de Janeiro, 5o vol.

BISPO, P. C., FROEHLICH, C. G. \& OLIVEIRA, L. G. (submmitted a). Stonefly (Plecoptera) fauna of streams in a moutainous area of Central Brazil: abiotic factors and nymph density. Revta. Brasil. Zool.

BISPO, P. C., FROEHLICH, C. G. \& OLIVEIRA, L. G. (submmitted b). Stonefly (Plecoptera) fauna of streams in a moutainous area of Central Brazil: composition and adult phenology. Revta. Brasil. Zool.

DINIZ-FILHO, J. A. F., OLIVEIRA, L. G. \& SILVA, M. M., 1998, Explaining the beta diversity of aquatic insects in "cerrado" streams from Central Brazil using multiple Mantel Test. Revta. Bras. Biol., 58(2): 223-231.

DOMINGUEZ, E. \& VALDEZ, J. M. B., 1992, Altitudinal replacement of Ephemeroptera in a subtropical river. Hydrobiologia, 246: 83-88.

DONALD, D. B., 1980, Deformities in Capniidae (Plecoptera) from the Bow River, Alberta. Can. J. Zool., 58: 682686

FERREIRA, M. J. N., 1990, Estudo da ordem Ephemeroptera do Córrego Pedregulho-Pedregulho, SP. Dissertação de Mestrado, FFCLRP, USP, 52p.

FROEHLICH, C. G., 1969, Studies on Brazilian Plecoptera 1. Some Gripopterygidae from the Biological Station at Paranapiacaba, State of São Paulo. Beitr. Neotrop. Fauna, 6(1): 17-39.

FROEHLICH, C. G., 1984, Brazilian Plecoptera 4. Nymphs of perlid genera from southeastern Brazil. Annles Limnol., 20(1-2): 43-48.
FROEHLICH, C. G. \& OLIVEIRA, L. G., 1997, Ephemeroptera and Plecoptera nymphs from riffles in low-order streams in southeastern Brazil. In: P. Landolt \& M. Sartori (eds.), Ephemeroptera \& Plecoptera: Biology-EcologySystematics. MTL, Fribourg, pp.180-185.

GILLER, P. S. \& MALMQVIST, B., 1998, The biology of streams and rivers. Oxford Univ. Press, Oxford, viii+296.

GONZALES DEL TÁNAGO, M., 1984, Distribution of Plecoptera in Duero basin (Spain). Annls Limnol., 20(12): 49-56.

HARPER, P. P. \& STEWART, K. W., 1996, Plecoptera. In: R. W. Merritt \& K. W. CUMMINS (eds.), An introduction to the aquatic insects of North America. 3th Edition, Kendall/Hunt Publishing Company, XIII+862p.

HART, D. D., 1992, Community organization in streams: the importance of species interactions, physical factors, and chance. Oecologia, 91: 220-228.

HASSAGE, R. L. \& STEWART, K. W., 1991, Use of substrate volume and void space to examine the presence of three stonefly species (Plecoptera) among stream habitats. Ann. Entomol. Soc. Am., 84(3): 309-315.

HASSAGE, R. L., DEWALT, R. E. \& STEWART, K. W., 1988, Aggregation of Pteronarcella badia nymphs and effects of interaction with Claassenia sabulosa (Plecoptera). Oikos, 53: 37-40.

HELLAWELL, J. M., 1989, Biological indicators of freshwater pollution and environmental management. Elsevier Science Publishers Ltd, London, IX+546p.

HYNES, H. B. N., 1970, The ecology of running waters. Liverpool University Press, Liverpool, xxiv $+555 \mathrm{p}$.

HYNES, H. B. N., 1976, Biology of Plecoptera. Annu. Rev. Entomol., 21: 135-153.

ILLIES, J., 1964, The invertebrate fauna of the Huallaga, a Peruvian tributary of the Amazon River, from the sources down to Tingo Maria. Verh. Internat. Verein. Limnol., 15: 1077-1083.

LILLEHAMMER, A. \& BRITTAIN, J. E., 1987, Longitudinal zonation of the benthic invertebrate fauna in the River Glomma, Eastern Norway. Fauna Norv. Ser., A8: $1-10$.

LIND, O. T., 1979, Handbook of common methods in limnology. The C. V. Mosby Company, 199p.

LUDWIG, J. A. \& REYNOLDS, J. F., 1988, Statistical ecology. A primer on methods and computing. John Wiley \& Sons, New York, XVIII+337p.

MACAN, T. T., 1962, Ecology of aquatic insects. Annu. Rev. Entomol., 7: 261-288.

McCAFFERTY, W. P., 1981, Aquatic entomology: the fishermen's and ecologist's ilustrated guide to insects and their relatives. Jones and Bartlett Publishers, London, $\mathrm{Xvi}+448$.

MERRITT, R. W. \& CUMMINS, K. W., 1996, An introduction to the aquatic insects of North America. 3th Edition, Kendall/Hunt Publishing Company, XIII+862p. 
MERRITT, R. W., CUMMINS, K. W. \& RESH, V. V., 1996, Collecting, sampling, and rearing methods for aquatic insects. In: R. W. Merritt \& K. W. Cummins (eds.), An introduction to the aquatic insects of North America. 3th Edition, Kendall/Hunt Publishing Company, XIII+862p.

NAVAS-PEREIRA, D. \& HENRIQUE, R. M., 1996, Aplicação de índices biológicos numéricos na avaliação da qualidade ambiental. Revta. Brasil. Biol., 56(2): 441-450.

NIMER, E., 1989, Climatologia do Brasil. IBGE, 421p.

OLIVEIRA, L. G., 1991, Estudo da fauna de Trichoptera do Córrego Pedregulho-Pedregulho, SP, com especial referência à família Hydropsychidae. Dissertação de Mestrado, FFCLRP, USP, 84p.

PENNAK, R. W., 1978, Fresh-water invertebrates of the United States. 2th Edition, John Wiley \& Sons, New York, XV+803.

PUIG, M. A., 1984, Distribution and ecology of the stoneflies (Plecoptera) in Catalonian rivers (NE-Spain). Annls Limnol., 20(1-2): 75-80.

RESH, V. H., 1979, Sampling variability and life history features: basic considerations of aquatic insect studies. J. Fish. Res. Board. Can., 36: 290-311.

ROSENBERG, D. M. \& RESH, V. H., 1993, Freshwater biomonitoring and benthic macroinvertebrates. Chapman \& Hall, London, IX+488p.

SCARSBROOK, M. R. \& TOWNSEND, C. R., 1993, Stream community structure in relation to spatial and temporal variation: a habitat templet study of two contrasting New Zealand streams. Freshw. Biol., 29: 395-410.
SCHROEDER-ARAUJO, L. T. \& CIPÓLLI, M. N., 1986, Organismos bentônicos como indicadores da qualidade de água de rios do Parque Estadual de Campos do Jordão, SP. Bolm. Inst. Pesca, 12(3): 77-83.

SIMPSON, K. W., 1980, Abnormalities in the tracheal gills of the aquatic insects collected from streams receiving chlorinated or crude oil wastes. Freshw. Biol., 10: 581583

STRAHLER, H. N., 1957, Quantitative analysis of watershed geomorphology. Amer. Geophys. Unio Trans., 33: 913920.

VANNOTE, R. L., MINSHALL, G. W., CUMMINS, K. W. L., SEDELL, J. R. \& CUSHING, C. E., 1980, The river continuum concept. Can. J. Fish. Aquat. Sci., 37: 130137.

WAIS, L. R., 1984, Two Patagonian basins - Negro (Argentina) and Valdivia (Chile) - as habitats for Plecoptera. Annls Limnol., 20(1-2): 115-122.

WIELGOSZ, S., ZOLTOWSKI, G. \& KUKLINSKA, B., 1982, The effect of organic sewage on the lithon zoocenosis in the Lyna River. Ekol. Polska, 30: 187-203.

WILliams, D. D. \& FELTMATE, B. W., 1992, Aquatic insects. Redwood Press Ltd., Melksham, XIV+358p. 